\title{
A Study on Intention of Use e-Procurement Systems for Public Institutions User
}

\author{
Woon-heok Ko ${ }^{1}$, Seung Ryul Jeong ${ }^{2}$, Kil-hwan Shin ${ }^{3}$ and Choon Yeul Lee ${ }^{4 *}$ \\ ${ }^{1}$ Public Procurement Service \\ ${ }^{2}$ Kookmin University, Graduate School of Business IT \\ ${ }^{3}$ LIG System \\ ${ }^{4}$ Kookmin University, Graduate School of Business IT \\ ${ }^{1}$ whko337@naver.com, ${ }^{2}$ srjeong@kookmin.ac.kr, ${ }^{3}$ khshin25@naver.com, \\ ${ }^{4}$ cylee@kookmin.ac.kr
}

\begin{abstract}
This study examined the usage intention for electronic e-Government procurement services among Public Institution Procurement Managers. The unified theory of acceptance and use of technology (UTAUT) model and the task-technology fit (TTF) model were combined to establish a study model. An hypothesis was formed and verified using SMART PLS. The results show that the UTAUT factors examined in this study effort expectance, social influence, and facilitating conditions influence usage intention. This study is significant in applying both the TTF and UTAUT models with strong explanatory power and identifying the characteristics of the tasks and technology that are required for the use of e-Procurement systems.
\end{abstract}

Keywords: e-Government, UTAUT, TTF, behavioral intention, security, e-Procurement, Online Service

\section{Introduction}

Electronic government (e-government) refers to servicing online and delivering information via Internet or other electronic means in order to better the public government's responsibility and transparency. The e-Government process is an online service or information procurement method that uses information technology such as the Internet or other electronic means to improve the responsibility, transparency effects, and efficiency of government and public organizations [1].

The stages of e-Government development occurred as follows: the preparation stage, involving administrative computerization during the Information Era before Internet utilization (1987-1995); the diffusion stage, focusing on online information provision and service after the introduction of the Internet (1996-2002); and the maturation stage, focusing on the provision, participation, and sharing of integrated online services (2003present). The "creative economy" and Government 3.0 have emerged through changes in the ICT technological environment, featuring machine-to-machine, cloud, and big data services for a mobile community that is pushing for e-Government; this signals eGovernment's entry into the maturation stage amid efforts to create a transparent government that communicates well with its citizens by breaking down the walls between government departments and offering personalized government services [2].

Business technology is building towards e-Government services based on Smart e-Gov, ubiquitous environments, and online environments. The Public Procurement Service is investing about 2.1 trillion $\mathrm{KRW}$, about $60 \%$ of public expenditures, to operate informatization businesses.

*Corresponding Author 
Table 1. Yearly Change in the Scale of Public Procurement Information Business Expenses

\begin{tabular}{|c|c|c|c|c|c|}
\hline $\begin{array}{c}\text { Category } \\
\text { (Units: 100 million KRW) }\end{array}$ & 2011 & 2012 & 2013 & 2014 & 2015 \\
\hline $\begin{array}{c}\text { Procurement Contract } \\
\text { Businesses }\end{array}$ & 339,812 & 347,346 & 383,733 & 339,479 & 263,061 \\
\hline Informatization Businesses & 19,283 & 21,383 & 21,215 & 21341 & 9,466 \\
\hline Negotiated Contracts & 12,268 & 15,037 & 14,530 & 15211 & 9,66 \\
\hline
\end{tabular}

This study seeks to understand the acceptance factors for e-Procurement systems users of public institutions.

\section{The Concept of the E-Procurement System}

The next-generation national marketplace is being enhanced to offer system transparency and efficiency, important facilitating factors for seamless procurement administration. Developments since 2014 have resulted in an e-Procurement system that offers the procurement support services of public Informatization businesses. It systematically offers a series of services, from business plans for informatization to business and achievement management, through the process shown in Figure 1 [3].

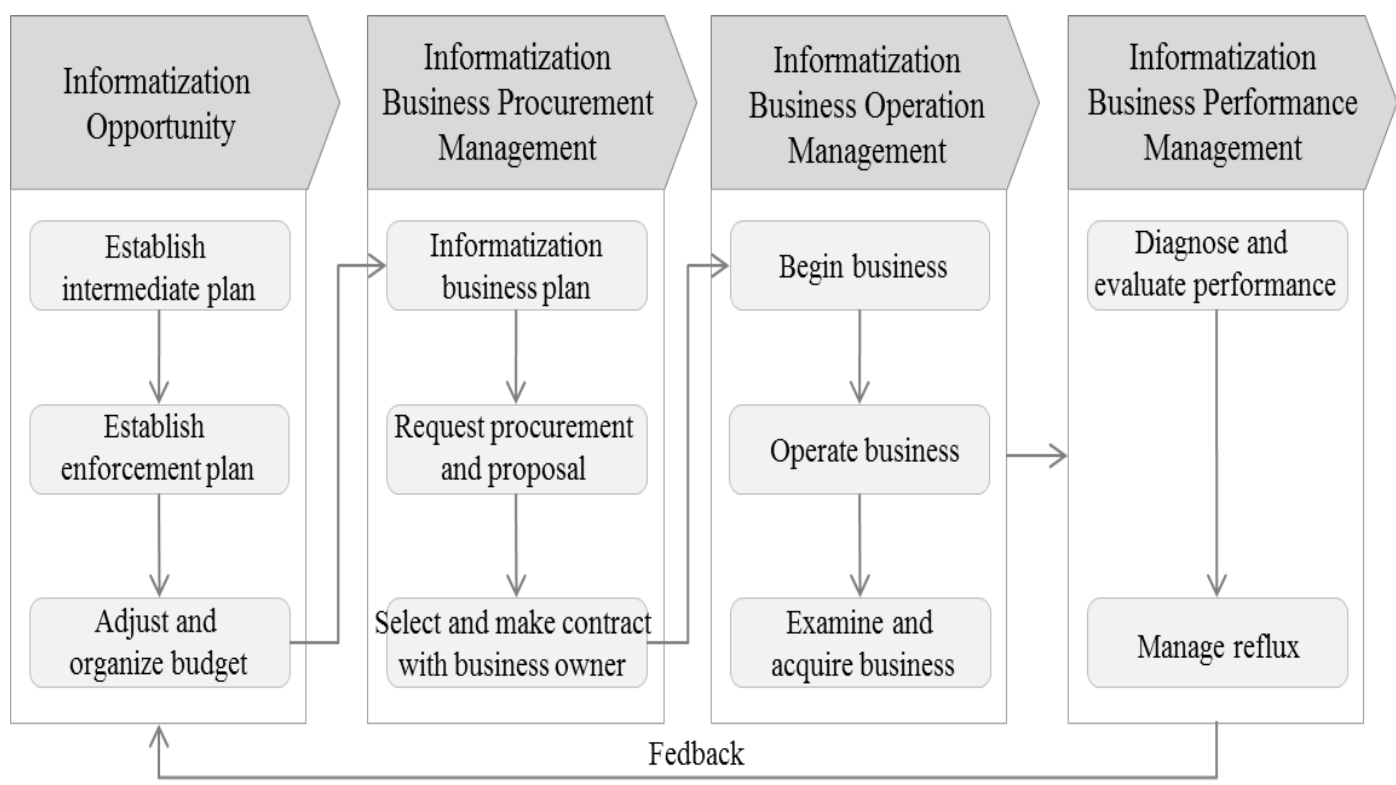

Figure 1. Functional Design Guide for the Information Task Support System of Central Administration Institutions 


\section{Theoretical Considerations}

\subsection{UTAUT(Unified Theory of Acceptance and Use of Technology)}

The UTAUT(Unified Theory of Acceptance and Use of Technology) is a model created by combining eight different theories and models of information technology, including the Theory of Reasoned Action (TRA), Theory of Planned Behavior (TPB), Technology Acceptance (TAM), Unified TAM-TPB model, Motivational Model (MM), Model of PC Utilization (MPCU), Innovation Diffusion Theory (IDT), and the Social Cognitive Theory (SCT). The UTAUT model is composed of four key concepts: performance expectance (PE), effort expectance (EE), social influence (SI), and facilitating conditions (FC). It also includes moderating variables such as age, gender, experience, and voluntary participation [4].

\subsection{TTF(Task Technology Fit)}

The TTF(Task Technology Fit) is the degree of harmony between the capability of information technology and task demands specifically, the capability of the information technology used to support tasks within an organization [5]. Information technology that fits the task characteristics and direction is accepted and helps improve the results. Good TTF capability promotes the acceptance of information technology among users, while poor TTF for complex tasks will reduce technology acceptance among users. For example, although mobile banking systems can be used anywhere at any time in this ubiquitous era, users will continue to prefer traditional online banking services if they remain in their office or if they are in an environment where there is no demand for mobile payments. The TTF model uses the TAM and UTAUT models from the perspective of acceptance among information technology users; this is being investigated by many studies in various fields [6]. The results of [6] offer empirical proof that models that combine the UTAUT and TAM (information technology acceptance models) with the TTF model (i.e., TAM or UTAUT + TTF) have greater explanatory power and provide deeper insight than when the models are used individually.

Information systems must be interconnected to achieve their goals in the organizational context. User acceptance can be the minimum standard for job maintenance (baseline) in the provision of information technology by organizations, unlike in the selection of information systems according to an individual's voluntary decision.

\section{Research Model and Data Analysis}

\subsection{Research Model}

We analyzed the acceptance factors for e-Procurement systems using partnership, security factors, TTF, and job crafting competence variables based on the UTAUT of Venkatesh et al.(2003) to fit the study purpose. We established a study model for a positive analysis of the relationship among the influences on the intention to use an eProcurement system of procurement Institution Procurement Managers.

The targets of this study are the characteristics of information technology acceptance factors, and the subjects are public institution employees who participated in eProcurement system training. Of the 171 survey respondents, $75 \%$ were male, $3.5 \%$ were in their $20 \mathrm{~s}, 38 \%$ were in their $30 \mathrm{~s}, 46 \%$ were in their $40 \mathrm{~s}$, and $3.5 \%$ were in their $50 \mathrm{~s}$. 


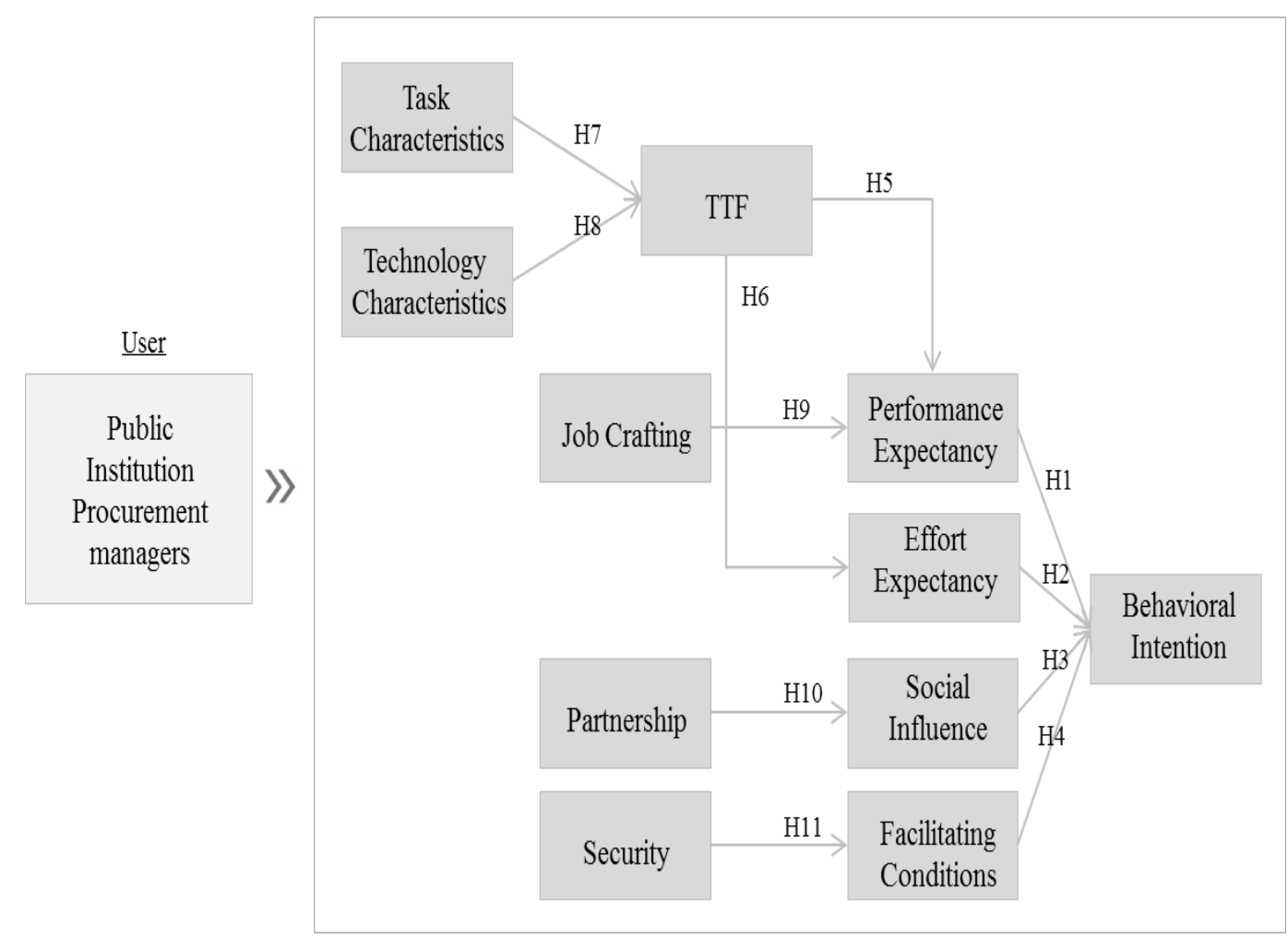

Figure 2. Research Model of Public Institution Procurement Managers

\subsection{Hypotheses}

In this study, 11 hypotheses are established to examine the behavioral intention of Public Institution Procurement Managers.

[Hypothesis-1] Performance Expectancy has a positive impact to Behavioral Intention of e-Procurement System.

[Hypothesis-2] Effort Expectancy has a positive impact to Behavioral Intention of eProcurement System.

[Hypothesis-3] Social Influence has a positive impact to Behavioral Intention of eProcurement System.

[Hypothesis-4] Facilitating Conditions has a positive impact to Behavioral Intention of e-Procurement System.

[Hypothesis-5] TTF has a positive impact to Performance Expectancy.

[Hypothesis-6] TTF has a positive impact to Effort Expectancy.

[Hypothesis-7] Task Characteristics has a positive impact to TTF.

[Hypothesis-8] Technology Characteristics has a positive impact to TTF.

[Hypothesis-9] Job Crafting has a positive impact to Performance Expectancy.

[Hypothesis-10] Partnership has a positive impact to Social Influence.

[Hypothesis-11] Security has a positive impact to Facilitating Conditions.

\subsection{Definition of Research Variables}

The research variables are defined as shown in Table 2 . They are extracted by reviewing variables used in previous studies. 
Table 2. Research Variables

\begin{tabular}{|c|c|c|}
\hline Factor & Variables & Source \\
\hline $\begin{array}{l}\text { Performance } \\
\text { expectancy }\end{array}$ & $\begin{array}{l}\text { Usefulness } \\
\text { Improved Work Productivity } \\
\text { Easy Work Process } \\
\text { Usefulness of Evidence }\end{array}$ & $\begin{array}{l}\text { V. Venkatesh, M.G. Morris } \\
\text { and G.B. Davis (2003) }\end{array}$ \\
\hline Effort expectancy & $\begin{array}{l}\text { Adaptability } \\
\text { Easy Cognition of Use } \\
\text { Work Applicable Convenience } \\
\text { Easy Learning } \\
\text { Based Technology Availability }\end{array}$ & $\begin{array}{l}\text { V. Venkatesh, M.G. Morris } \\
\text { and G.B. Davis (2003) }\end{array}$ \\
\hline Social influence & $\begin{array}{l}\text { Recommended Intention } \\
\text { Extent of Convenience Awareness } \\
\text { Awareness of Availability } \\
\text { Use Intention and Desire } \\
\text { Popular Generality }\end{array}$ & $\begin{array}{l}\text { V. Venkatesh, M.G. Morris } \\
\text { and G.B. Davis (2003) }\end{array}$ \\
\hline Facilitating Conditions & $\begin{array}{l}\text { Organizational support } \\
\text { Retention of knowledge } \\
\text { Business Support } \\
\text { Compatibility of Business processing style }\end{array}$ & $\begin{array}{l}\text { V. Venkatesh, M.G. Morris } \\
\text { and G.B. Davis (2003) }\end{array}$ \\
\hline Task Characteristics & $\begin{array}{l}\text { Accuracy of business promotion } \\
\text { Repeatability of proposal task } \\
\text { Management of SW business } \\
\text { Share of business information }\end{array}$ & $\begin{array}{l}\text { Tao Zhou, Yaobin Lu and } \\
\text { Bin Wang }(2010) \\
\text { Goodhue \& } \\
\text { Thompson(1995) }\end{array}$ \\
\hline $\begin{array}{l}\text { Technology } \\
\text { Characteristics }\end{array}$ & $\begin{array}{l}\text { Function of proposal task } \\
\text { Function of business mgmt. } \\
\text { Function of User Interface } \\
\text { Prompt real-time service }\end{array}$ & $\begin{array}{c}\text { Tao Zhou, Yaobin Lu and } \\
\text { Bin Wang }(2010) \\
\text { Goodhue \& } \\
\text { Thompson(1995) }\end{array}$ \\
\hline Task Technology Fit & $\begin{array}{l}\text { Adequacy of proposal task } \\
\text { Adequacy of business Mgmt. } \\
\text { Adequacy of internet business } \\
\text { environment } \\
\text { Adequacy of e-procurement service }\end{array}$ & $\begin{array}{l}\text { Tao Zhou, Yaobin Lu and } \\
\text { Bin Wang }(2010) \\
\text { Goodhue \& } \\
\text { Thompson(1995) } \\
\text { Dishaw \& Strong(1999) }\end{array}$ \\
\hline Partnership & $\begin{array}{l}\text { Expectancy of resource sharing } \\
\text { interdependence } \\
\text { degree of trust } \\
\text { cooperation of information business }\end{array}$ & Khan, K.B(1996) \\
\hline Security & $\begin{array}{l}\text { Safety of Internet Security } \\
\text { Safety of Information Infringement } \\
\text { Safety for Data Leakage } \\
\text { Work Performance Safety }\end{array}$ & $\begin{array}{l}\text { S. H. Jeon, N. L. Park and J. } \\
\text { J. Lee (2011) }\end{array}$ \\
\hline $\begin{array}{l}\text { Job Crafting } \\
\text { Competency }\end{array}$ & $\begin{array}{l}\text { Increase of structural business support } \\
\text { Decrease of negative business support } \\
\text { Increase of social business support } \\
\text { Increase of challenging task requirement }\end{array}$ & $\begin{array}{l}\text { Tims, M., and Bakker, A.B } \\
\text { (2010) }\end{array}$ \\
\hline Behavioral Intention & $\begin{array}{l}\text { Use Intention Level } \\
\text { Unconscious Use Awareness } \\
\text { Future Use Planning } \\
\text { Expendability Acceptance Level }\end{array}$ & $\begin{array}{l}\text { V. Venkatesh, M.G. Morris } \\
\text { and G.B. Davis (2003) }\end{array}$ \\
\hline
\end{tabular}




\subsection{Data Analysis Results and Hypothesis Testing}

We performed a positive analysis on the data collected through the study model shown in Figure 3.

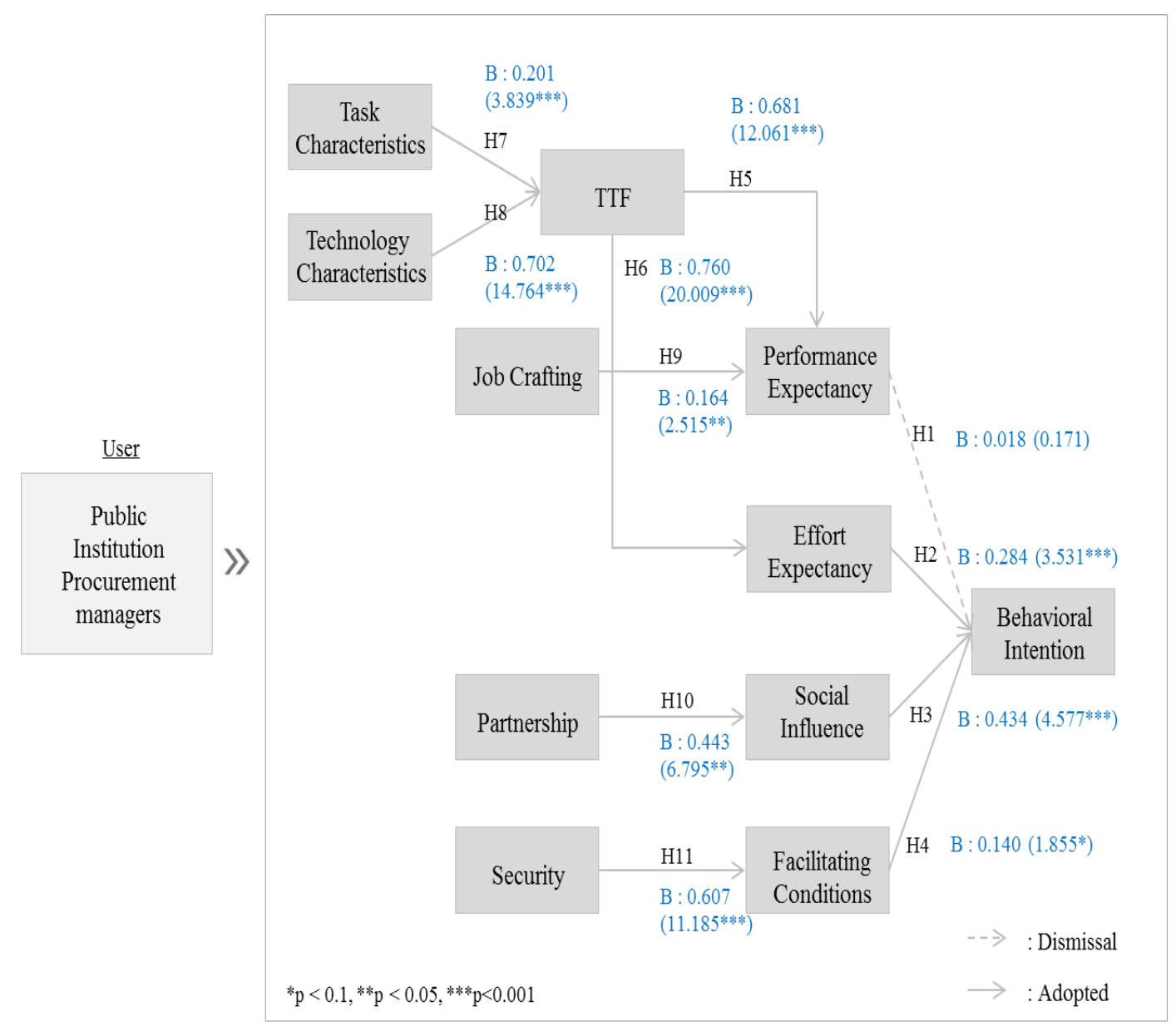

Figure 3. Analysis Results of PLS

We summarize the results for the study hypotheses below. The path analysis results between effort expectance and intention to use in the UTAUT model had no significant influence, as effort expectance was dismissed $(\beta=0.018, \mathrm{t}=0.171)$ from intention to use (UBI). However, the UTAUT's effort expectance $(\beta=0.284, \mathrm{t}=3.531$, $\mathrm{p}<0.001$ : adopted $)$, social influence $(\beta=0.434, \mathrm{t}=4.577 \mathrm{p}<0.001$ : adopted $)$, and facilitating conditions $(\beta=0.140, \mathrm{t}=1.855 \mathrm{p}<0.1$ : adopted $)$ did have a significant influence on intention to use an e-Procurement system.

The TTF model analysis results show that task characteristics $(\beta=0.201, \mathrm{t}=3.839$, $\mathrm{p}<0.001$ adopted) and technological characteristics $(\beta=0.702, \mathrm{t}=14.764, \mathrm{p}<0.001$ : adopted) had a significant influence on TTF. For TTF, an antecedent UTAUT factor, performance expectance $(\beta=0.681, \mathrm{t}=12.061, \mathrm{p}<0.001$ : adopted $)$ and effort expectance $(\beta=0.760, t=20.009, p<0.001$ : adopted $)$ had a strongly significant positive definition $(+)$ effect.

Finally, job crafting competence $(\beta=0.164, \mathrm{t}=2.515, \mathrm{p}<0.05$ : adopted $)$, also an antecedent UTAUT factor, had a significant definition (+) effect on the effort expectance of the UTAUT, while partnership $(\beta=0.443, \mathrm{t}=6.795, \mathrm{p}<0.001$ : adopted) had a significant effect on social influence. Security $(\beta=0.607, \mathrm{t}=11.185 \mathrm{p}<0.001$ : adopted $)$ had $\mathrm{a}$ significant effect on facilitating conditions. 
Table 3. Summary of Hypothesis Verification Results for Intention to Use eProcurement Systems of Public Institution Procurement Managers

\begin{tabular}{|c|c|c|c|c|c|c|c|}
\hline \multicolumn{2}{|c|}{ Explanation } & \multirow{2}{*}{$\begin{array}{c}\text { Path } \\
\text { Coefficient } \\
0.018\end{array}$} & \multirow{2}{*}{$\begin{array}{c}\text { Sample } \\
\text { Mean (M) } \\
0.020\end{array}$} & \multirow{2}{*}{$\begin{array}{c}\text { Standard } \\
\text { Deviation } \\
\text { (STDEV) }\end{array}$} & \multirow{2}{*}{$\begin{array}{c}\begin{array}{c}\mathrm{t}- \\
\text { statistics }\end{array} \\
0.171\end{array}$} & \multirow{2}{*}{$\begin{array}{c}\begin{array}{c}\mathrm{p}- \\
\text { values }\end{array} \\
0.865\end{array}$} & \multirow{2}{*}{$\begin{array}{l}\text { Adoption } \\
\text { Dismissa }\end{array}$} \\
\hline $\mathrm{H} 1$ & $\begin{array}{c}\text { PEE -> } \\
\text { UBI }\end{array}$ & & & & & & \\
\hline $\mathrm{H} 2$ & $\begin{array}{c}\text { EFE -> } \\
\text { UBI }\end{array}$ & $0.284 * * *$ & 0.282 & 0.080 & 3.531 & 0.000 & Adopted \\
\hline H3 & $\begin{array}{c}\text { SOI -> } \\
\text { UBI }\end{array}$ & $0.434 * * *$ & 0.434 & 0.095 & 4.577 & 0.000 & Adopted \\
\hline $\mathrm{H} 4$ & $\begin{array}{c}\text { FAC -> } \\
\text { UBI }\end{array}$ & $0.140 *$ & 0.144 & 0.075 & 1.855 & 0.064 & Adopted \\
\hline H5 & $\begin{array}{c}\text { TTF -> } \\
\text { PEE }\end{array}$ & $0.681 * * *$ & 0.678 & 0.056 & 12.061 & 0.000 & Adopted \\
\hline H6 & $\begin{array}{c}\text { TTF -> } \\
\text { EFE }\end{array}$ & $0.760 * * *$ & 0.762 & 0.038 & 20.009 & 0.000 & Adopted \\
\hline $\mathrm{H} 7$ & $\begin{array}{c}\text { TAC -> } \\
\text { TTF }\end{array}$ & $0.201 * * *$ & 0.206 & 0.052 & 3.839 & 0.000 & Adopted \\
\hline H8 & $\begin{array}{c}\text { TEC -> } \\
\text { TTF }\end{array}$ & $0.702 * * *$ & 0.698 & 0.048 & 14.764 & 0.000 & Adopted \\
\hline H9 & $\begin{array}{c}\text { JOB -> } \\
\text { PEE }\end{array}$ & $0.164 * *$ & 0.168 & 0.065 & 2.515 & 0.012 & Adopted \\
\hline $\mathrm{H} 10$ & $\begin{array}{c}\text { PTS -> } \\
\text { SOI }\end{array}$ & $0.443 * * *$ & 0.454 & 0.065 & 6.795 & 0.000 & Adopted \\
\hline H11 & $\begin{array}{c}\text { SEC -> } \\
\text { FAC }\end{array}$ & $0.607 * * *$ & 0.613 & 0.054 & 11.185 & 0.000 & Adopted \\
\hline
\end{tabular}

$* \mathrm{p}<0.1, * * \mathrm{p}<0.05, * * * \mathrm{p}<0.001$

\section{Conclusion}

Information technology (IT) increases the efficiency and effectiveness of private and government task processes and supports managerial decision making. It is recognized as a strategic tool for improving task production and enhancing the competitiveness of organizations [6]. South Korea's e-Government is changing its eGovernance to strengthen information transparency and fairness, having passed through the preparation, diffusion, and maturation stages according to the direction and purpose of the government's policies. Various services are being offered and are evolving towards a system where businesses can bid for public informatization in a way that makes public information open to citizens. This study examined the intentions of procurement businesses that use the e-Procurement system for bidding.

We presented a UTAUT expansion model after adding variables such as security, partnership, job crafting competence, and TTF by considering changes in software policies, including recent legal changes concerning public and government information businesses. We also derived study results on the intention to use eProcurement systems of public institution procurement managers. 
First, we confirmed the usability of the UTAUT. We examined usage intention among potential users of each e-Procurement system group by employing performance expectance, effort expectance, social influence, and facilitating conditions as the key conceptual factors of the UTAUT. The path analysis results show that all variables (except effort expectance) had path coefficients $(\beta)$ at significant levels, indicating a significantly positive influence on public institution procurement managers.

Second, the TTF model, reflecting the task and technological characteristics from the perspective of users of e-Procurement systems, was combined with the UTAUT model. The combined model displayed greater explanatory power and insight than do studies that have analyzed user acceptance by employing only the UTAUT. This study offers significant results that are similar to those in [12].

Security, job crafting as antecedents to explain UTAUT's independent variables have been additionally given and the effect relations between UTAUT's independent variables and the added variables have been analyzed. The public institutions placing orders and the potential supplier-users both, as a result of the analysis, can be inferred as sub explanatory factors affecting UTAUT's independent variables: that are performance expectancy, social influence, facilitating conditions.

In future more generalized discussions about e-government service can be encouraged by looking at ways to vitalize e-procurement support system according to user type via a longitudinal analysis and researching into the factors affecting user intention to accept e-procurement system by considering types of e-government services( G2B, G2C, G2G etc.) and user satisfaction.

\section{References}

[1] A. Muir and C. Oppenheim, "National information policy developments worldwide in electronic government", Journal of Information Science, vol. 28, (2002), pp. 173-186.

[2] National Information Association, "2008-2002 e-Government white paper", Seoul, (2014).

[3] K. W. Heok, "A study on user behavioral intention of e-procurement service : Focused on e-government system”, Kookmin University, Seoul, (2015).

[4] V. Venkatesh, M. G. Morris and G. B. Davis, "User acceptance of information technology: Toward a unified view", MIS Quarterly, vol. 27, (2003), pp. 425-478.

[5] M. T. Dishaw and D. M. Strong, "Extending the Technology Acceptance Model with Task Technology Fit constructs", Information and Management, vol. 36, (1999), pp. 9-21.

[6] W. J. Ketiiinger, V. Grover, S. Guha, and A. H. Segars, "Strategic information systems revisited: A study in sustainability and performance", MIS Quarterly, vol. 8, (1994), pp. 31-58.

[7] D. L. Goodhue and R. L. Thompson, "Task Technology Fit and Individual Performance”, MIS Quarterly, vol. 19, no. 2, (1995), pp. 213-236.

[8] M. T. Dishaw and D. M. Strong, "Extending the Technology Acceptance Model with Task Technology fit Constructs", Information and Management, vol. 36, no. 1, (1999), pp. 9-21.

[9] M. Tims and A. B. Bakker, "Job Crafting: Towards a New Model of Individual Job Redesign", SA Journal of Industrial Psychology vol. 36 no. 2, (2010), pp. 1-9.

[10] S. H. Jeon, N. L. Park and J. J. Lee, "Study on the Factors Affecting the Intention to Adopt Public Cloud Computing Service", Entrue Journal of Information Technology, vol. 10, no. 2, (2011), pp. 97-112.

[11] K. B. Kahn, "Interdepartmental Integration: A Definition with Implications for Product Development Performance", Journal of Product Innovation Management, vol. 13, no. 2, (1996), pp. 137-151.

[12] T. Zhou, Y. Lu and B. Wang, "Integrating TTF and UTAUT to explain mobile user adoption", Computers in Human Behavior, vol. 26, (2010), pp. 760 -767. 


\section{Authors}

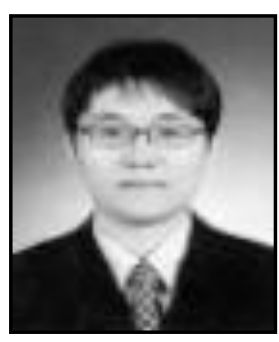

Woon-heok Ko, 2004: Kookmin Uiversity, Graduate School of Business IT, (M.D.), 2015: Kookmin University, Graduate School of Business IT, (Ph.D.), 2014 Now : Dept. of PMO, Public Procurement Service. Research Area: e-Government, ISP, Big Data.

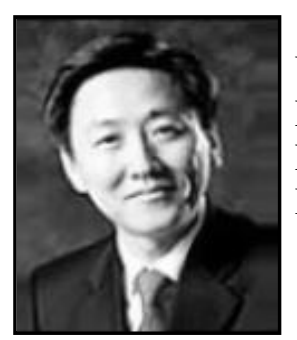

Seung Ryul Jeong, 1985: Dept. of Economics, SOGANG University. 1989: Dept. of MIS, Univ. of Wisconsin(M.D.). 1995: Dept. of MIS, Univ. of South Carolina(Ph.D.). Research Area: Process Management, Peocess Architecture, ERP, IT Gaverance, ISP, e-Government.

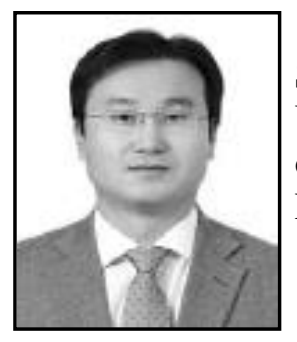

Kil-hwan Shin, 2000: Dept. Of MIS, Dankook Graduate School (M.D.), 2001: Dept. Of Information Science, Kookmin University, (M.D.), 2013: Kookmin University, Graduate School of Business IT,(Ph.D.). Research Area: Mobile Service, Cost Engineering.

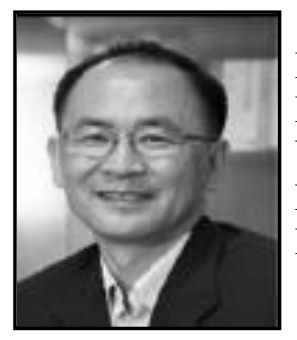

Choon Yeul Lee (Corresponding Author), 1979: Dept. Of Industrial Engineering, Seoul National Univ. 1983: Dept. Of Business Administration, Seoul National Univ.(M.D.), 1990: Univ. Of Michigan Computer\&IS(Ph.D.), 1994 Now: Dept. Of MIS, Kookmin University, Professor. Research Area: Database, Business Intellegence. 
International Journal of $u$ - and e- Service, Science and Technology Vol.9, No. 10 (2016) 